dr Urszula Bejma

UNIWERSYTET KARDYNAŁA STEFANA WYSZYŃSKIEGO W WARSZAWIE

\title{
Rola i znaczenie pracy w życiu człowieka na kanwie encykliki Laborem exercens
}

\section{Wstęp}

W życiu każdego człowieka istnieją wartości, dla których żyje i dzięki którym się realizuje. Są to, między innymi: rodzina, dom, poczucie szczęścia, zdrowie, a także praca, która ma ogromny wpływ na szeroko rozumiany rozwój człowieka i jednocześnie jest czynnikiem warunkującym współpracę ludzi oraz grup społecznych; wręcz wpływa na całokształt życia społecznego. Rola pracy w życiu człowieka jest tak znacząca, że oddziałuje ona na jego życie już w okresie poprzedzającym właściwą karierę zawodową. Już dla kilkuletniego dziecka staje się ona przedmiotem refleksji, marzeń i aspiracji, aby w późniejszym okresie życia stać się przedmiotem określonych, zaplanowanych działań. Młody człowiek, planując swą przyszłość, bierze pod uwagę zwłaszcza pracę zawodową i życie rodzinne. Od momentu rozpoczęcia kariery zawodowej praca wyznacza miejsce, które człowiek zajmuje w społeczeństwie, spełniając rolę czynnika decydującego o jego pozycji społecznej oraz położeniu materialnym, od których zależy z kolei osobiste powodzenie i satysfakcja w innych dziedzinach życia. Praca zatem oddziałuje na wyznawane przez jednostkę wartości, na jej stosunek do samej siebie, do otaczającej ją rzeczywistości społecznej. 


\section{Wartość pracy w życiu człowieka}

Pracę można traktować na różne sposoby. Dla jednych jest to powołanie, dla innych źródło zarobkowania i szansa na samorealizację. Dzięki pracy powstają dobra materialne, tworzone są też wartości kulturowe i społecznie znaczące usługi. Poprzez pracę definiujemy samych siebie, rozwijamy nasze silne strony. To praca określa nasze miejsce w społeczeństwie, wyznacza nam cele i stawia przeszkody do pokonania, dzięki którym możemy się rozwijać. W znaczeniu potocznym pracę definiuje się najczęściej jako celową działalność człowieka, połączoną z wysiłkiem fizycznym, zmierzająca do przekształcenia rzeczywistości przyrodniczej i społecznej dla potrzeb własnych i potrzeb społeczeństwa. Jednostka poprzez pracę zapewnia sobie byt i zaspokojenie potrzeb, najpierw podstawowych, a w dalszej kolejności drugorzędnych. Praca jest więc sposobem i metodą zapewnienia sobie i społeczeństwu elementarnych, tak materialnych, jak i duchowych, warunków egzystencji. Praca jako dobrowolna forma działalności człowieka, wypływająca z jego obowiązku wobec społeczeństwa, zyskuje na wartości szczególnie wtedy, kiedy trudno ją zdobyć i gdy byt materialny jednostek i ich rodzin jest zagrożony.

Pracę rozpatrywać można w różnych aspektach:

- społecznym - jako kulturowo uwarunkowany proces społeczny będący podstawowym czynnikiem rozwoju osobowości człowieka;

- filozoficznym - jako dążenie do osiągnięcia preferowanych przez jednostki wartości (jednostkowych i społecznych), osiągnięcia pozytywnych i eliminacji negatywnych ocen moralnych;

- ekonomicznym - jako realne korzyści: gospodarcze, materialne i finansowe, płynące z wykonywanej pracy, będące podstawą dobrobytu jednostki i społeczeństwa; 
- historycznym - jako zmiany zachodzące w ciągu wieków w życiu społeczeństw ${ }^{1}$.

Praca pełni nadto trzy różne funkcje: podmiotową, przedmiotową i społeczną:

- funkcja podmiotowa - jednostka podejmuje działania w celu zaspokojenia własnych podstawowych potrzeb zapewniających warunki egzystencji, a także potrzeb wyższego szczebla, jak potrzeba realizacji. Praca daje korzyści materialne, dzięki którym człowiek czuje się bezpiecznie pod względem ekonomicznym psychicznym i społecznym. „Jako osoba jest tedy człowiek podmiotem pracy. Jako osoba pracuje, wykonuje różne czynności przynależące do procesu pracy, a wszystkie one, bez względu na charakter, mają służyć urzeczywistnieniu się jego człowieczeństwa, spełnianiu osobowego powołania, które jest mu właściwe z racji samego człowieczeństwa" (LE 6)

- funkcja przedmiotowa - jednostka ingeruje w przyrodę ze względów czysto ekonomicznych. To podporządkowanie jest wynikiem ciągłych zmian potrzeb indywidualnych człowieka. Proces, jakim jest praca, zobowiązuje człowieka do wywiązania się z obowiązku tworzenia cywilizacji i dóbr kultury;

funkcja tworzenia więzi społecznych - jednostka integruje się społecznie i ta integracja ma olbrzymi wpływ na jej rozwój. Obecność innych ludzi ma wpływ na sposób myślenia, procesy spostrzegania i procesy motywacyjne ${ }^{3}$.

1 J. Stępień, Socjologia pracy i zawodu, Poznań 2001, s. 18.

2 Jan Paweł II, Laborem Exercens - tekst i komentarze, Lublin 1986.

3 M. Kalinowski, Praca, [w:] Uzależnienia. Fakty i mity, red. I. Niewiadomska, Lublin 2005, s. 9. 
Właściwe podejście do pracy jest tylko w momencie, gdy funkcja podmiotowa ma pierwszeństwo nad funkcją przedmiotową: „Prawdą jest, że człowiek jest przeznaczony i powołany do pracy, to jednak nade wszystko praca jest dla człowieka, a nie człowiek dla pracy" (LE 6). W momencie odwrócenia tej kolejności rodzi się patologia pracy. Jedną z takich patologii jest uzależnienie od pracy, czyli pracoholizm.

Diagram: Wielowymiarowe funkcje pracy

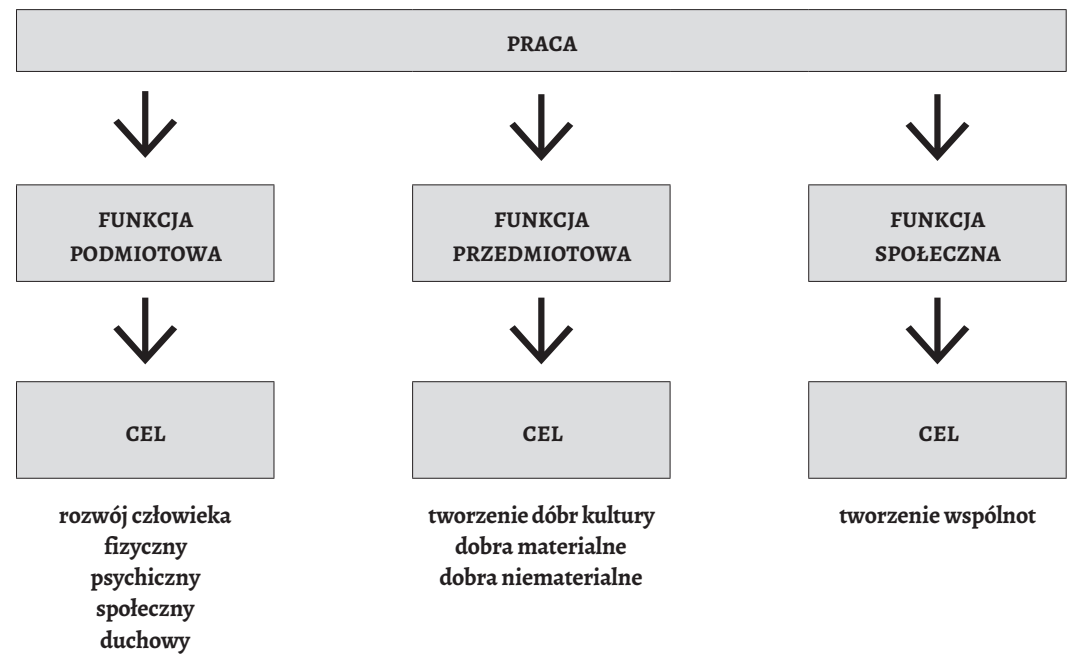

Źródło: M. Kalinowski, Praca. Uzależnienia, [w:] Fakty i mity, red. I. Niewiadomska, Lublin 2005, s. 42.

\subsection{Zaangażowanie w pracę}

Zaangażowanie w pracę jest to „wielkość psychologicznej identyfikacji jednostki z pracą", związana bezpośrednio z motywacją stymulującą chęć wykonywania obowiązków i satysfakcją, jaką z niej 
czerpiemy4. Motywacja to przede wszystkim zapłata, jaką otrzymujemy za wykonywaną pracę, i powód, dla którego pracujemy coraz więcej. Poprzez pracę realizujemy się i możemy pokazać innym, ile tak naprawdę jesteśmy warci, gdyż praca dla niektórych z nas jest sposobem na podniesienie własnej wartości. Mówiąc o kimś, że jest zapracowany i zaangażowany, często mamy na myśli dobrego fachowca i człowieka sukcesu. Osoba zaczynająca karierę zawodową pragnie się wykazać i angażuje się bez reszty w to, co robi. Często zostaje poza godzinami w pracy, niejednokrotnie bierze pracę do domu i nieustannie potrafi myśleć nad nowym projektem, który może być szansą na przyszły awans. Taka osoba to źródło zysków dla firmy i wzór dla innych pracowników. Właśnie takich pracowników firmy poszukują, a niektóre, widząc opłacalność zatrudnienia takiej osoby, za wszelką ceną starają się ją do organizacji przywiązać. W tym celu oferują wszystko to, co do życia potrzebne, prestiżowe stanowisko i nieodłączny temu ogólny szacunek, dobre wynagrodzenie i różnego typu benefity, aby zminimalizować wszelką aktywność niezawodową ${ }^{5}$. Wielkie zaangażowanie w pracę wiąże się z nieustannym o niej myśleniem, a stres i czynniki, jakie temu towarzyszą, potrafią być dla nas szczególnie szkodliwe.

4 D. P. Schultz, S. E. Schultz, Psychologia a wyzwania dzisiejszej pracy, przeł. G. Kranas, Warszawa 2002, s. 315.

5 Informacja zaczerpnięta z rozmowy przeprowadzonej przez Pawła Berłowskiego z Tomaszem Ochinowskim i Waldemarem Grzywaczem, Firmy jak sekty, „Personel i Zarządzanie” 2004 nr 4, s. 25. 


\subsection{Praca jako źródło satysfakcji człowieka}

Zaangażowanie w wykonywaną pracę jest ściśle związane z bezpośrednią lub pośrednią satysfakcją, jaką czerpiemy z jej wykonywania. Satysfakcja pracowników staje się coraz istotniejszą kwestią także dla firm, które ich zatrudniają, oraz dla ich klientów. Faktem jest, że satysfakcja pracowników z wykonywanej pracy przekłada się w znacznym stopniu na satysfakcję klientów danej instytucji. Wyznacza ona stosunek pracowników do firmy, ich lojalność wobec pracodawcy, ale także określa relacje między współpracownikami, stosunek do klientów oraz poziom zaangażowania w działalność firmy i relacje z przełożonymi. Dla pracodawcy zaś satysfakcja zawodowa jego personelu jest gwarancją wysokiej jakości i wydajności.

Satysfakcję zawodową można określić inaczej jako zadowolenie z pracy, które jako kategoria psychosocjologiczna jest wypadkową wielu czynników materialnych i pozamaterialnych. Pojęcie to wiąże się ze stanem równowagi pomiędzy potrzebami i oczekiwaniami pracownika wobec pracy a ich zaspokojeniem. Satysfakcja z pracy jest zatem wykładnikiem i jednocześnie wyznacznikiem określonych postaw wobec pracy, zawodu czy zakładu pracy; to wypadkowa satysfakcji z tego, co się ma, i niezadowolenia z tego, czego jeszcze brakuje. To wypadkowa zaspokojonych potrzeb i niezaspokojonych aspiracji ${ }^{6}$.

Amerykański socjolog Robert Dubin sklasyfikował ludzi ze względu na ich stosunek do pracy. Do pierwszej grupy zaliczył ludzi zorientowanych na pracę, do drugiej - zorientowanych na życie społeczne. Ludzie zorientowani na pracę to ci, dla których praca jest

6 A. Sarapata, K. Doktor, Elementy socjologii przemystu, Warszawa 1965, s. 231. 
czymś pierwszoplanowym. Z jednaj strony aktywność zawodowa dostarcza im ogromnego zadowolenia oraz wymiernych gratyfikacji, ale bywa też źródłem frustracji i wielu rozczarowań. W drugiej grupie znalazły się osoby, dla których praca jest przede wszystkim sposobem na zdobycie środków służących do realizacji celów oraz dążeń, które są związane z wielowymiarowym funkcjonowaniem człowieka w życiu społecznym. Dubin wyróżnił jeszcze trzecią, marginalna grupę, składająca się z osób, które charakteryzuje zmienność dążeń oraz brak zdecydowanych zainteresowań7.

Zdaniem psychologa Janusza Reykowskiego zadowolenie z pracy to „pozytywny stan emocjonalny bądź powstający pod wpływem kontaktu z określonym przedmiotem, czynnością względnie oddziaływaniem, bądź też występujący jako uogólniona reakcja charakteryzująca stan jednostki jako całości”" Według tegoż autora satysfakcja może być doraźna, czyli chwilowa, lub stała. Doraźna satysfakcja jest rzeczywistym procesem emocjonalnym, który towarzyszy aktualnemu, zazwyczaj krótkotrwałemu, doświadczeniu. W przypadku zadowolenia stałego mówimy o emocji dodatniej w formie latentnej. Mamy tu do czynienia nie z procesem, ale z gotowościa do reakcji emocjonalnych. Zadowolenie stałe zaś jest dużo bardziej skomplikowane niż zadowolenie doraźne. Po pierwsze, nie wyklucza ono równoczesnego występowania negatywnych reakcji emocjonalnych. Po drugie, nie musi ono być odczuwane i bez dodatkowych

7 D. Dobrowolska, Praca zawodowa jako wartość w życiu jednostki, [w:] Problematyka i metody badań nad zadowoleniem z pracy, red. A. Sarapata, Wrocław 1973, s. 9-33.

8 J. Reykowski, Zadowolenie i niezadowolenie a wyniki pracy (szkic teoretyczny), [w:] Problematyka i metody badań nad zadowoleniem z pracy, red. A. Sarapata, Wrocław 1973, s. 33-45. 
okoliczności może nie być zauważone ani przez daną osobę, ani przez jej otoczenie. Charakteryzując przyczyny zadowolenia, wspomniany autor zwraca uwagę na zaspokajanie potrzeb i spełnianie oczekiwań. Zaspokajanie potrzeb i spełnianie oczekiwań ciągle na tym samym poziomie może jednak przestać budzić zadowolenie; wtedy konieczne staje się wprowadzenie niewielkich zmian w strukturze potrzeb i oczekiwań człowieka. Dużą rolę odgrywają tu czynniki zewnętrzne tworzące tło - gdy pogarsza się sytuacja ogólna, a sytuacja danej osoby nie zmienia się, zadowolenie z wykonywanej pracy utrzyma się, a nawet może wzrosnąć. Polepszenie natomiast sytuacji ogólnej przy utrzymaniu sytuacji jednostki na niezmienionym poziomie będzie powodować spadek zadowolenia9.

W literaturze przedmiotu istnieją jeszcze inne kategoryzacje czynników mających wpływ na zadowolenie z pracy. Saul William Gellerman wyróżnia trzy źródła zadowolenia z pracy. Pierwszym i jednocześnie najważniejszym są motywy skłaniające pracownika do podjęcia danej pracy ze względu na osobiste potrzeby. Drugim postępowanie pracodawcy, kierowników i wynikające stąd nadzieje dla pracownika. Trzecim z kolei źródłem są złudzenia i mity, jakim ulegają poszczególni pracownicy na skutek błędnej oceny i interpretacji własnych możliwości, warunków pracy lub warunków społeczno-ekonomicznych, w których żyją ${ }^{10}$.

Inną, równie interesującą interpretację podają Danny Cox i John Hoover, zdaniem których zarządzanie ludźmi to umiejętność uczynienia z pracy szansy na przynoszący pracownikowi satysfakcję rozwój

9 Por. J. Reykowski, Zadowolenie i niezadowolenie a wyniki pracy..., dz. cyt., s. 33-45.

10 H. Januszek, J. Sikora, Socjologia pracy, Poznań 2000, s. 178. 
osobowości. Oznacza to, że pracodawca każdemu z zatrudnionych powinien pomagać $w$ wyzwalaniu jego talentów, bowiem ludzie, którzy się rozwijają i nie obawiają nowych wyzwań, są bardziej radośni, szczęśliwi, czują się spełnieni i usatysfakcjonowani. Wzrasta wówczas morale, co przekłada się na wyższą wydajność, a zespół staje się bardziej stabilny. Wśród samych czynników podnoszących morale i mających wpływ na satysfakcję zawodową wymienia się: interesującą pracę, entuzjastyczne przyjmowanie nowych pomysłów pracodawców, wysoko i ambitnie ustalane cele, docenianie wysiłków oraz sprawiedliwe traktowanie ludzi, sprawiedliwe wynagradzanie, wspieranie rozwoju osobistego, integrację, poszerzanie odpowiedzialności ${ }^{11}$.

Inny badacz zagadnienia, niemiecki socjolog Ludwig von Friedeburg, przeprowadził badania, z których wynika, że dla robotników przyczynami zadowolenia z pracy są nade wszystko: pewność zatrudnienia, przyjemne warunki pracy, kompetentni i życzliwi przełożeni, możliwość awansu, wysoki zarobek, możliwość realizacji własnej inicjatywy, dobre warunki przyuczenia się do zawodu, dogodny czas pracy, lekka praca ${ }^{12}$.

Z kolei polscy socjologowie Henryk Januszek i Jan Sikora, analizując badania amerykańskich badaczy interesujących się problemem zadowolenia z pracy, wymienili następujące czynniki zadowolenia z pracy:

- rozumienie wartości pożytku z wykonywanej pracy, przekonanie, że robi się coś, co warto robić;

11 M. Kopertyńska, Motywowanie pracowników: teoria i praktyka, Warszawa 2008, s. 251-252.

12 M. Kopertyńska, Motywowanie pracowników: teoria i praktyka, dz. cyt., s. 178. 
- zaufanie do kierownictwa, które zna się na rzeczy i ma właściwy stosunek do podwładnych;

- świadomość uczestnictwa w ważnej pracy oraz zaufanie do własnej grupy roboczej; możność wypowiadania się w sprawach dotyczących grupy; przekonanie, że to, co jest dobre dla grupy, jest dobre także dla wszystkich jej członków;

- poczucie bycia potrzebnym do wykonywania określonej pracy; dobre traktowanie, wykorzystywanie zdolności oraz uznanie ze strony przełożonych;

- sprawiedliwa i słuszna praca, która wystarcza na przyzwoite utrzymanie; możliwość większego zarobku w przypadku zwiększenia wydajności pracy;

- perspektywa awansu, możliwości wykazania się zdolnościami i podwyższania kwalifikacji;

- stałość pracy, opieka na wypadek choroby i starości;

- świadomość tego, co się dzieje w miejscu pracy; rzetelna informacja o wszelkich zmianach mających wpływ na prace grupy; liczenie się ze zdaniem podwładnych;

- dobre warunki pracy, sprawny sprzęt i narzędzia ${ }^{13}$.

Ci sami autorzy wyodrębnili spośród części badań poświęconych postawom wobec pracy trzy podstawowe punkty widzenia powiązań satysfakcji, zadowolenia z pracy i wykonywaną pracą. Są to:

- pogląd, że zadowolenie prowadzi do lepszego wykonywania zadań, zwiększenia produkcji, a tym samym zysku;

- pogląd, że związek zadowolenia z wykonaniem pracy zawiera wiele zmiennych pośredniczących; satysfakcja z pracy nie jest

13 H. Januszek, J. Sikora, Socjologia pracy, dz. cyt., s. 179. 
już bowiem uważana za wstępny warunek wysokiej produktywności, a sam charakter związku pomiędzy zadowoleniem a pracą jest przedmiotem wielu istotnych pytań, na przykład: czy związek ten jest bezpośredni?, czy jest on odczuwalny?, czy jest wzajemny?

- pogląd, iż wysoki poziom wykonywanej pracy prowadzi do zadowolenia; to znaczy, że dobre wykonywanie zadań może prowadzić do nagród, które z kolei prowadzą do satysfakcji; satysfakcja jest więc skutkiem dobrze wykonanej pracy ${ }^{14}$.

Inną, wspomnianą wcześniej właściwością pracy jest fakt, że człowiek w jej procesie może zaspokajać wiele swoich potrzeb. Praca dawno przestała być traktowana jedynie jako źródło pozyskiwania środków niezbędnych do przeżycia czy w kategoriach możliwości zdobywania przywilejów socjalnych. Uznaje się bowiem powszechnie, że czas spędzony w pracy, kontakty zawodowe, realizacja powierzonych zadań dają możliwość realizowania różnorodnych potrzeb człowieka, nie tylko pośrednio - za pomocą zdobytych w zamian za pracę środków finansowych, ale także wprost - dzięki temu, że sama praca stwarza okoliczności pozwalające te potrzeby realizować.

Badania przeprowadzone w wielu firmach wskazują, że sensowne działanie i możliwość spełnienia siebie w pracy są dla wielu ważniejsze niż podwyżka płac. Kto bowiem pracuje tylko dla pieniędzy, nie odczuwa przyjemności, nie widzi perspektyw rozwoju osobistego, nie kształtuje entuzjazmu - czeka jedynie na comiesięczną rekompensatę za działanie nieprzynoszące satysfakcji.

Postrzeganie pracy jako naturalnej drogi do zdobywania środków do życia, a także nawiązywania kontaktów z ludźmi (pozwalających

14 J. Stępień, Socjologia pracy i zawodu, dz. cyt., s. 18. 
zaspokajać potrzeby społeczne) lub pozyskiwania prestiżowego statusu czyni z niej tak zwaną wartość instrumentalną. Jeśli jednak przyznaje jej się status czynnika, który daje człowiekowi szanse podnoszenia własnej wartości, poczucia zadowolenia z tego, co na bieżąco czyni, poszerzania horyzontów, gdy jest lubiana i ceniona przez pracownika i stanowi samoistne źródło jego zadowolenia i satysfakcji, wówczas traktuje się ją jako wartość samą w sobie i określa mianem wartości autotelicznej.

Obecnie w nowoczesnych firmach pracownik ma relatywnie więcej szans na znalezienie się w sytuacji, gdy praca staje się dla niego wartością samą w sobie. Wynika to między innymi z rozwijania demokratycznych form zarządzania, wzrostu ogólnego poziomu intelektualnego ludzi wskutek rozwoju różnych form edukacji, wzrostu liczby i typów zakładów pracy, zwłaszcza w dużych aglomeracjach, co zwiększa możliwość wyboru pracy najbardziej pożądanej, odpowiadającej własnym upodobaniom. Szanse te wzmacnia również upowszechniająca się tendencja do dostrzegania w pracowniku jego umiejętnościach i zaangażowaniu - ważnej przesłanki powodzenia firmy. Pracodawcy coraz częściej rozumieją i uwzględniają fakt, że bardzo wiele zależy od woli i kwalifikacji zatrudnionych $\mathrm{w}$ firmie osób. Warunkiem zasadniczym szans wykreowania pracy jako wartości autotelicznej jest przywiązanie przez pracodawcę wagi do potrzeb pracownika, trafne ich odczytywanie, zrozumienie mechanizmu powiązań pomiędzy realizacją celów firmy a zaspokojeniem interesów osób w niej zatrudnionych.

Zarówno satysfakcja, jak i niezadowolenie wiążą się z tym, co i jak motywuje pracownika, odzwierciedla stopień zadowolenia (niezadowolenia) pracownika z wykonywanej pracy. Satysfakcja jako zjawisko wielowymiarowe może być nie tylko wynikiem zaspokojenia potrzeb, 
ale też następstwem porównania osiągniętego efektu w stosunku do zachowania jednostki. Stanowi zatem końcowy etap i rezultat motywowania pracownika, czynnik kontrolujący i korygujący zachowania człowieka w celu osiągnięcia przez niego w przyszłości lepszego efektu, nagrody i większej satysfakcji. Może być wreszcie przyczyną (siłą sprawczą) zachowania jednostki skłaniająca ją w przypadku niezadowolenia z wykonywanej pracy do jej zmiany. W ostatnim przypadku niezadowolenie pełni rolę reduktora gotowości do działania w danym miejscu pracy-budzi nieufność i niechęćc ${ }^{15}$.

Satysfakcja z pracy zawodowej lub jej brak przekłada się bezpośrednio na jakość życia jednostki, rozumianej jako wypadkowa kryteriów oceny świata zewnętrznego, warunków obiektywnych (na przykład poziom dochodu, warunki mieszkaniowe, sposób spędzania wolnego czasu) oraz warunków subiektywnych (zdrowie, doświadczenie, wykształcenie). Innymi słowy jakość życia człowieka, często określana także jako dobrostan, szczęście czy zadowolenie z życia, to ocena własnego życia jako całości oraz różnych jego sfer. Te subiektywne aspekty jakości życia sprowadzają się do określenia stanów psychicznych człowieka, subiektywnych korelatów zaspokajania własnych potrzeb i osiągania założonych celów. Są one wynikiem poznawczej oceny własnych relacji z otoczeniem, to znaczy własnych osiągnięć i niepowodzeń w zmaganiach z nim oraz oceny szans realizowania własnych dążeń, pragnień i planów. W tym kontekście aktywność człowieka, a więc i jego praca, jest ukierunkowana dwojako: na siebie i na otoczenie. Zmieniając siebie,

15 S. Borkowska, Systemy motywowania pracowników. Zarządzanie zasobami ludzkimi, [w:] Tworzenie kapitału ludzkiego organizacji, red. H. Król, A. Ludwiczyński, Warszawa 2008, s. 120. 
człowiek przywraca utracone zasoby i pomnaża je. Zmieniając świat, może go uczynić wrogim lub mniej przyjaznym albo atrakcyjnym i przyjaznym dla innych ${ }^{16}$.

O poziomie satysfakcji z życia decydują dwa jego aspekty: ilościowy i jakościowy. Dla kształtowania poczucia jakości życia ważne jest, czy znaczące potrzeby mogą być w ogóle realizowane oraz czy jest dostępna wystarczająca ilość wartości gratyfikujących. Ważne jest również, w jakim zakresie może być zaspokojona ważna potrzeba, zaś brak niektórych zasobów kompensowany przez inne, jednak niższe dochody bądź ich brak są najsilniej odczuwane, ponieważ nie pozwalają na realizację wielu innych potrzeb: materialnych, społecznych i kulturalnych. Dlatego tak bardzo istotne jest posiadanie pracy oraz zadowolenie płynące z jej wykonywania, aby w konsekwencji odczuwać satysfakcję z życia.

Tak rozumiane pojęcie satysfakcji jest analogiczne do pojęcia uczucia zadowolenia. Uczucie to jest pojęciem pozytywnym, ale uwarunkowanym subiektywnie. Indywidualne oczekiwania, system wartości, a także wcześniejsze doświadczenia zawodowe wiążą się z tym, że różne osoby w odmienny sposób postrzegają analogiczne sytuacje, dlatego nie ma uniwersalnej recepty na podniesienie poziomu odczuwania satysfakcji zawodowej.

\subsection{Wartość ekonomiczna pracy}

Prawo do pracy jest jednym z podstawowych praw społecznych człowieka. Międzynarodowy Pakt Praw Gospodarczych, Społecznych

16 Z. Ratajczak, Psychologia pracy i organizacji, Warszawa 2007, s. 159. 
i Kulturalnych wyraźnie stwierdza, iż prawo do pracy dotyczy każdego człowieka, który powinien uzyskać możliwości utrzymania się poprzez swobodnie wybraną i przyjętą pracę ${ }^{17}$. Podobnie Powszechna Deklaracja Praw Człowieka ONZ stwierdza, iż każdy człowiek ma prawo do pracy, do swobodnego wyboru oraz godnych i zadowalających warunków, jak również do ochrony przed bezrobociem. Praca bowiem stanowi podstawowy wymiar bytowania człowieka na ziemi, dlatego jest jedną z fundamentalnych rzeczywistości ludzkiego życia. Jawi się ona jako dobro człowieka, ponieważ przez nią realizuje on sam siebie, zaspokaja swoje podstawowe potrzeby oraz potrzeby członków rodziny.

W swej najgłębszej istocie prawo do pracy oznacza moralne uprawnienie do zatrudnienia, które decyduje o zdobyciu środków do życia. Czesław Strzeszewski, dokonując analizy owego zagadnienia, stwierdza, iż „zdobywając przez pracę środki zaspokojenia potrzeb swoich i swojej rodziny, człowiek zdobywa niezależność w dziedzinie gospodarczej; prawa do pracy domaga się jego wolność, również jako postulat prawa natury"18. Podobnie papież Pius XII podkreślał, że każdemu człowiekowi przysługuje prawo do pracy, ponieważ jest ona niezbędnym środkiem utrzymania życia rodzinnego, jak również udoskonalenia osobowości człowieka ${ }^{19}$. Praca jako określona forma działania ma zapewnić osobie ludzkiej godne warunki do codziennego utrzymania.

17 http://www.unesco.pl/fileadmin/user_upload/pdf/Powszechna_Deklaracja_Praw_Czlowieka.pdf, art 23, s. 4 (12.03.2013).

18 C. Strzeszewski, Katolicka nauka społeczna, Lublin 1994, s. 595.

19 Pius XII, Przemówienie wigilijne wygłoszone 24 grudnia 1942 r., [w:] Dokumenty nauki społecznej Kościoła, red. M. Radwan, L. Dyczewski, A. Stanowski, Rzym-Lublin, t. 1, s. 192. 
Każdy człowiek, aby mógł funkcjonować w społeczeństwie, powinien mieć materialne zaplecze, bazę, na którą składają się między innymi: mieszkanie, pożywienie, ubranie, możliwość leczenia, rekreacji, utrzymania lub pomocy materialnej rodzinie, dzieciom...

Pierwszym z wymienionych elementów warunkujących prawidłowe funkcjonowanie jednostki jest mieszkanie. Zapewnia ono możliwość schronienia przed niekorzystnymi warunkami klimatycznymi, zaspokojenia potrzeby odpoczynku, jak również dostarcza minimum intymności. Człowiek potrzebuje do życia również pożywienia, które nabywa drogą kupna za wypracowane uprzednio środki pieniężne. Kolejnym obszarem wydatków rodzinnego budżetu są wydatki związane ze zdrowiem. Mimo iż $\mathrm{w}$ nowoczesnych państwach usługi zdrowotne są "darmowe", gdyż pokrywane są z funduszu powszechnych ubezpieczeń, to najczęściej nie dotyczy to wszystkich świadczeń związanych z pielęgnacją zdrowia, w tym na przykład leków. Od higieny życia zatem, od odpoczynku czy rekreacji zależy zdrowie fizyczne i psychiczne zarówno jednostki, jak i całego społeczeństwa. Brak środków finansowych powoduje, że człowiek rezygnuje z wszelkich form rekreacji, wyjazdów wakacyjnych, co może mieć negatywne skutki na jego życie zawodowe.

Ekonomia życia codziennego narzuca określony sposób funkcjonowania każdego człowieka: inaczej funkcjonują osoby zamożne, a inaczej te, których budżet jest skromny. Pierwsze są w stanie zaspokoić wszystkie potrzeby natury ekonomicznej i nie muszą dokonywać cięć w wydatkach, aby spełnić wymagania wszystkich podstawowych potrzeb na odpowiednim poziomie. Takiego komfortu nie mają osoby biedne, które z konieczności muszą dokonywać 
racjonalnych wyborów i pomniejszać koszty funkcjonowania w tych wymiarach ${ }^{20}$.

\section{Praca jako narzędzie doskonalenia człowieka}

Jednym z wymiarów ludzkiego działania w myśl encykliki Laborem exercens jest panowanie człowieka nad ziemia; drugi, nie mniej istotny element stanowi to, co ta aktywność sprawia w samym podmiocie działającym. Praca bowiem jest „drogą, na której człowiek realizuje właściwe sobie «panowanie» $\mathrm{w}$ świecie widzialnym, czyniąc sobie ziemię poddaną. Ów trud zaś jest faktem powszechnie znanym, bo powszechnie doświadczanym" (LE 9).

Podstawową analizę ludzkiego działania określić można, używając terminologii Karola Wojtyły, jako przechodnią i nieprzechodnią. „Jest przechodnia, o ile zmierza poza podmiot, o ile obiektywizuje się $\mathrm{w}$ jakimś wytworze. Jest nieprzechodnia natomiast, o ile pozostaje w podmiocie; o ile stanowi o jego immanentnej jakości czy też wartości, o ile konstytuuje jego istotowe fieri. Człowiek bowiem, działając, nie tylko spełnia czyny, ale także staje się poprzez nie sobą: spełnia siebie w nich"21. Mając więc na uwadze taką strukturę ludzkiego działania, można rozpatrywać, czy i na ile praca pomaga człowiekowi w doskonaleniu siebie, w byciu bardziej człowiekiem.

W myśl podjętych przez autorkę rozważań zasadniczą odpowiedź na tak postawiony problem znajdujemy w tekście encykliki: „Praca

20 W. Majkowski, Rodzina polska w kontekście nowych uwarunkowań, Kraków 2010, s. 54-57.

21 K. Wojtyła, Problem konstytuowania się kultury poprzez ludzka praxis, „Roczniki Filozoficzne" 1979 nr 21, s. 12. 
jest dobrem człowieka - dobrem jego człowieczeństwa - przez pracę bowiem człowiek nie tylko przekształca przyrodę, dostosowując ją do swoich potrzeb, ale także urzeczywistnia siebie jako człowiek, a także poniekąd bardziej «staje się człowiekiem»" (LE 9). Praca zatem jest przemianą świata, a nade wszystko przemianą samego człowieka. Pracując, człowiek tworzy nowe wartości i w ten sposób przyczynia się do doskonalenia swojej osobowości, zarówno w odniesieniu do praxis, jak również doskonałości „bycia”22.

Doskonalenie się i spełnianie człowieka poprzez pracę, o czym często mówi Jan Paweł II, ma także wymiar moralny. Praca bowiem, choć jest konieczna do zaspokojenia potrzeb życiowych człowieka, "o wiele bardziej jest koniecznością w sensie moralnym niż biologicznym. Człowiek urzeczywistnia się poprzez działalność twórcza, dzięki niej lepiej zaczyna rozumieć swą kondycję, to, że jest obrazem Boga, Pana i Władcy stworzenia; poprzez pracę staje się bardziej człowiekiem... Praca zawsze musi podnosić godność ludzkiej osoby, nigdy nie powinna jej poniżać"23.

Znaczenie pracy nie ogranicza się tylko do zakresu wartości utylitarnych, ekonomicznych. Praca pełni ważną funkcję wspomagającą człowieka w tym, aby stawał się lepszym, duchowo dojrzałym, bardziej odpowiedzialnym, aby mógł realizować swoje ludzkie powołanie, zarówno sam, jak i we wspólnocie z innymi: z rodziną, która stanowi naturalne prawo i powołanie człowieka oraz pierwszą szkołę pracy, a także ze społeczeństwem, z narodem, „do którego człowiek przynależy na podstawie szczególnych więzi kultury i historii” (LE 10).

22 J. Majka, Katolicka nauka społeczna, Rzym 1987, s. 367-367.

23 Jan Paweł II, „Praca, która jest drogą ku wyzwoleniu”. Bogota-spotkanie z mieszkańcami „barrios”, „L’Osservatore Romano” wyd. pol. (1986) nr 7, s. 15. 


\section{Zakończenie}

Praca jest wpisana w życie każdego człowieka, angażując nieustannie jego siły fizyczne $i$ władze duchowe. $Z$ tej też racji nie może dziwić fakt, że papież Jan Paweł II, który w swej pierwszej encyklice zaznaczył, że „człowiek jest pierwszą i podstawową drogą Kościoła, drogą wyznaczona przez samego Chrystusa”"24, podjął w swoim nauczaniu problematykę ludzkiej pracy, która jest kluczowym wymiarem życia osobistego i społecznego człowieka, elementem konstytuującym jego rozwój zarówno indywidualny, jak i społeczny. Należy zaznaczyć, że ojciec święty od początku swojego pontyfikatu, niestrudzenie starał się przywrócić człowiekowi świadomość podmiotowości i godności jego pracy, dając tym samym doktrynalną podstawę nauki o roli i znaczeniu pracy w życiu człowieka.

24 Jan Paweł II, Encyklika Redemptor hominis, 14.

Urszula Bejma, Rola i znaczenie pracy w życiu człowieka na kanwie encykliki Laborem exercens, [w:] Rodzina między pracą a ptacą. Refleksja nad spoteczną myśla encykliki Laborem exercens Jana Pawła II, red. Robert Kantor, Marek Kluz, Józef Młyński, Kraków 2016, s. 23-41. DOI: http://dx.doi.org/10.15633/9788374385015.03 